Walczak B., 2005, Rola państwa w dziejach języka polskiego, „Poznańskie Spotkania Językoznawcze”, t. XIV, red. Z. Krążyńska, Z. Zagórski, Poznań, s. 85-95.

Walczak B., 2015, Religijno-kościelny czynnik sprawczy rozwoju języka polskiego, w: Język tożsamości, seria: Język. Religia. Tożsamość, t. 9, red. G. Cyran, E. Skorupska-Raczyńska, Gorzów Wielkopolski, s. 185-200.

Witaszek-Samborska M., 1992, Wyrazy obcego pochodzenia we współczesnej polszczyźnie (na podstawie słowników frekwencyjnych), Poznań.

Witaszek-Samborska M., 1993, Zapożyczenia z różnych języków we współczesnej polszczyźnie (na podstawie słowników frekwencyjnych), Poznań. 


\title{
O zapomnianych XIX-wiecznych wyrazach i związkach wyrazowych z kręgu leksyki religijnej (na przykładzie dokumentów Zgromadzenia Sióstr Opatrzności Bożej)
}

\author{
Forgotten nineteenth-century words and expressions \\ of religious vocabulary (on the example of the documents \\ of the Sisters of Divine Providence)
}

\author{
S. Małgorzata Wojtaszek \\ Wydział Filologii Polskiej i Klasycznej, Uniwersytet im. Adama Mickiewicza w Poznaniu, \\ ul. Fredry 10, 61-701 Poznań, Polska; \\ e-mail: mwojtaszek83@gmail.com
}

\begin{abstract}
Abstrakt
W artykule zaprezentowane zostały wyrazy i związki wyrazowe z kręgu leksyki religijnej, które funkcjonowały w XIX-wiecznej polszczyźnie, a które nie występują we współczesnych tekstach o tematyce religijnej. Źródłem badanego materiału językowego są teksty XIX-wiecznych dokumentów Zgromadzenia Sióstr Opatrzności Bożej stanowiących normę prawną tej rodziny zakonnej: Zbiór Ustaw Zgromadzenia Panien Opatrzności (1857) i Ustawy Zgromadzenia Sióstr Opatrzności z 1882 roku. Analiza etymologiczno-strukturalna i semantyczna wyodrębnionych jednostek językowych, poświadczona cytatami odpowiednich zapisów, w których te wyrazy i połączenia występują, wskazuje, że prawie wszystkie wymienione w artykule zapomniane wyrazy i związki wyrazowe wyekscerpowane z dokumentów Zgromadzenia to archaizmy leksykalne. Archaizmem rzeczowym jest leksem pokutnica. Najczęściej powtarzającymi się w analizowanym materiale wyrazami są rzeczowniki admonitorka i pokutnica, następnie próbantka i kolejno frazeologizmy dawać pokuty, cnota gruntowna, rzeczownik szafarka i wyrażenie postęek duchowny. Leksemy cnota i pokora nabrały z kolei nieco negatywnego zabarwienia, zwłaszcza w rzeczywistości laickiej.
\end{abstract}

Słowa kluczowe: język religijny; leksyka; etymologia; semantyka; archaizmy leksykalne; archaizmy rzeczowe.

\footnotetext{
Abstract

The article presents words and expressions from the religious vocabulary which functioned in the nineteenth-century Polish language, and which do not exist in contemporary texts about religion. The source of the study is the nineteenth-century documents of the Sisters of Divine Providence that constitute the legal norms of that religious community: Zbiór Ustaw Zgromadzenia Panien Opatrzności (Collection of Regulations of the Assembly of Maidens of Providence) from 1857 and Ustawy Zgromadzenia Sióstr Opatrzności (Laws of the Sisters of Providence) from 1882. Etymological -structural and semantic analysis of the chosen linguistic units, attested by appropriate quotations in which these words appear, shows that almost all the forgotten words and expressions mentioned in the article taken from the documents of the Congregation of the Sisters of Divine Providence are
} 
lexical archaisms. The word pokutnica (penitent) is an archaism. Most often repeated in the analysed material words are the nouns admonitorka and pokutnica, then próbantka and idioms dawać pokuty, cnota gruntowna, the noun szafarka and idiom postępek duchowny. The words cnota (virtue) and pokora (humility) gained a slightly negative connotation, especially in secular reality.

Keywords: religious language; lexicon; etymology; semantics; lexical archaisms; material archaisms.

W artykule zaprezentowane zostaną wyrazy i związki wyrazowe z kręgu leksyki religijnej, które funkcjonowały w XIX-wiecznej polszczyźnie, a które nie występują ani we współczesnych tekstach o tematyce religijnej, ani w środowisku sióstr zakonnych. Źródłem badanego materiału językowego są teksty XIX-wiecznych dokumentów Zgromadzenia Sióstr Opatrzności Bożej stanowiących normę prawną tej rodziny zakonnej. Są to: Zbiór Ustaw Zgromadzenia Panien Opatrzności (1857, cz. I-II) i Ustawy Zgromadzenia Sióstr Opatrzności (1882)1, a więc teksty będące przykładem języka religijnego w sensie szerszym². Jako źródło badań zostały wybrane dokumenty polskiego zgromadzenia zakonnego; konsekracja zakonna jest bowiem pełniejszym wyrażeniem chrztu, a chrzest Polski, którego 1050. rocznica przypada w tym roku (2016), umożliwił powstanie wspólnot zakonnych na terenach wchodzących w skład państwa polskiego. Artykuł zawierać będzie analizę etymologiczno-strukturalną i semantyczną wyodrębnionych jednostek językowych, poświadczoną cytatami odpowiednich zapisów, w których te wyrazy i połączenia występują. W ekscerpcji pomijam leksemy, w których zachodzą różnice ortograficzne (np. fundacya). Zgromadzony materiał konfrontuję z notacjami leksykograficznymi z wybranych słowników ogólnych (historycznych i współczesnych) języka polskiego, których spis zamieszczam na końcu artykułu.

Zgromadzenie Sióstr Opatrzności Bożej powstało w połowie XIX w. we Lwowie. Jego założycielką jest Sługa Boża Antonina Mirska (1822-1905). Pierwotnie działalność Zgromadzenia skupiała się na prowadzeniu domów poprawy, sierocińców i ochronek (Wojtaszek 2016). Na skutek zmiany granic Polski po II wojnie światowej i polityki władz komunistycznych Zgromadzenie utraciło wiele placówek i zmuszone zostało do zmiany profilu działalności. Siostry po 1989 r. podjęły na nowo - zgodną z celem Zgromadzenia - działalność opiekuńczo-wychowaw-

${ }^{1}$ Oryginały dokumentów (rękopisy, których fragmenty przytaczam w oryginalnym kształcie językowym) są przechowywane w Archiwum Zgromadzenia Sióstr Opatrzności Bożej w Grodzisku Mazowieckim.

${ }^{2}$ Renata Grzegorczykowa, odwołując się do definicji języka religijnego sformułowanej w Encyklopedii katolickiej, rozróżnia dwa obszary rozumienia języka religijnego - węższy i szerszy. Do języka religijnego sensu largo należą, zdaniem badaczki, wszelkie wypowiedzi dotyczące sfery religijnej, np. ogłoszenia parafialne, zapowiedzi przedślubne, komunikaty hierarchów itp., a do języka religijnego rozumianego węziej - wypowiedzi o specjalnej funkcji, niezwiązanej z innymi typami wypowiedzi, umożliwiające uczestnictwo w sacrum. Badaczka zaznacza przy tym, że oddzielenie języka religijnego w sensie ścisłym od rozumienia w sensie szerokim nie przebiega ostro (Grzegorczykowa 2012: 259). 
czą w przedszkolach, domach dziecka i młodzieżowych ośrodkach socjoterapii, ale kontynuują też podjętą po wojnie pracę w domach opieki społecznej, katechizują dzieci i młodzież, pracują w parafiach (Wojtaszek 2016).

„Liczba jednostek leksykalnych nieustannie się zmienia” (Markowski 2009: $162)^{3}$. Z systemu odchodzą wyrazy nieużywane, a wchodzą wyrazy i frazeologizmy, które nazywają nieznane wcześniej desygnaty lub są nowym sposobem wyrażania ekspresji (Markowski 2009: 162). Procesy te znajdują swoje odbicie również w leksyce religijnej.

Wyrazem, który występuje w analizowanych dokumentach, a który nie pojawia się we współczesnych tekstach o tematyce religijnej, jest leksem admonitor$k a$ : „Obowiązkiem Admonitorki jest, Przełożonej całego Zgrom:, te udzielać uwagi które sądzi ku dobru całego Zgrom: lub saméj Przełożonéj istotnie potrzebne" (ZU II, 94). Admonitorka to derywat (sufiks -orka) od łac. admonitio "upomnienie, przygana, reprymenda' opatrzonego w Stowniku tacińsko-polskim kwalifikatorem dawny (Kumaniecki 1983: 14). Zadaniem admonitorki było udzielanie rad $\mathrm{i}-\mathrm{w}$ razie konieczności - upomnień przełożonej generalnej lub przełożonej lokalnej.

W badanym materiale występuje leksem chór, oznaczający miejsce, w którym przebywają zakonnice w czasie wspólnych modlitw: „Nowicyuszki mają być odosobnione od Profesek, z któremi tylko wspólnie w chórze i refektarzu zostają" (ZU II, 33). Chór (od łac. chorus) w znaczeniu 'zespół duchownych lub zakonników uczestniczących w nabożeństwie; ich miejsce w czasie nabożeństwa' notuje ESJP XVII-XVIII, a także SJPD. Definiensy wyrazu chór w SStp, SPXVI, SL, SWil, SW i USJP nie zawierają tego znaczenia. Notacje leksykograficzne leksemu chór pozwalają sądzić, że jego znaczenie uległo rozszerzeniu, a następnie zawężeniu. Pierwsze znaczenie rzeczownika chór w USJP brzmi: 'zespół śpiewaków

3 Janusz Korczak wyjaśniał swoim uczniom, że ,język ludzki, czyli mowa ludzka, żyje, karmi się, choruje, robi rozmaite interesy - może być bardzo biedna albo bogata. [...] im mądrzejszy jest jakiś naród, im więcej wie i więcej umie, tym więcej ma rozmaitych wyrazów i z każdym rokiem rodzą mu się nowe wyrazy, [...] Jeżeli język sam sobie na razie nowego wyrazu wymyśleć [sic!] nie potrafi, to go sobie pożycza tymczasem. [...] Kto pożycza, ten powinien oddać - i język oddaje pożyczone wyrazy. Weźcie sobie, panowie Francuzi, z powrotem swój wyraz: kontent, bo my już mamy swój wyraz - no, jaki? A - zadowolony. Weźcie sobie, panowie Niemcy, swoje: spacerować, bryftregier, banhof, bo my mamy: przechadzka, listonosz, dworzec. [...] Widzicie więc, że rodzą się w języku nowe wyrazy, że rośnie, pożycza i oddaje, kiedy sobie na własny wyraz zapracuje, że jest coraz bogatszy, że coraz łatwiej nim ludziom myśleć i mówić... Zdziwicie się jeszcze bardziej, kiedy wam powiem, że niektóre wyrazy w nim umierają. Wyobraźcie sobie, że mówicie do kolegów: Azali zagracie z nami w palanta? - Zaiste, zagramy - odpowiadają koledzy. Widzicie, sami się śmiejecie. Azali, zaiste - są to wyrazy stare, zgrzybiałe, do codziennej mowy wcale nie zdatne. Są one siwe i poważne i usłyszeć je dzisiaj możecie tylko w kościele. Takich wyrazów, które już zupełnie umarły albo umierają - jest bardzo wiele" (Korczak 1992: 407-414).

${ }^{4}$ Za skrótem ZU (oznaczającym Zbiór Ustaw Zgromadzenia Panien Opatrzności) odnotowano najpierw cyfrą rzymską numer części, a po przecinku - numer strony. 
wykonujących wspólnie pieśni lub partie wokalne większych utworów muzycznych, często z towarzyszeniem instrumentów'.

Dawniej w Zgromadzeniu Sióstr Opatrzności Bożej siostrę, która opiekowała się siostrami chorymi, nazywano infirmerką: „Ile razy która uczuje się słabą, niech uwiadomi o tem zaraz infirmerkę, asystentkę lub samą przełożoną [...]" (ZU I, 11). Nazwę infirmerka (pierwotnie infirmarka) utworzono sufiksem feminatywnym - $k a$ od rzeczownika infirmaria 'sala chorych'. Leksem ten rejestrują SL, SWil, SW i SJPD. Nie notuje go już USJP. Wyraz ten nie pojawia się we współczesnych tekstach religijnych, nie jest też używany w środowisku sióstr, których dotyczą analizowane dokumenty.

W badanym materiale kobiety, które chcą skończyć z prostytucją, nauczyć się właściwie funkcjonować i pracować na swoje utrzymanie, nazywane są pokutnicami: „Ponieważ celem powołania naszego jest [...] zbawienie czy pokutnic, czy dzieci nam powierzonych, Mistrzyni sama powinna być przejęta gorliwością o chwałę Bożą, i zbawienie dusz, gdyż najskuteczniejszym środkiem do wykształcenia Nowicyuszek jest przykład Mistrzyni" (ZU II, 18). Wyraz ten jest formacją żeńską od leksemu pokutnik 'człowiek odprawiający pokutę, zwłaszcza w widoczny sposób, np. biczując się, umartwiając' (USJP). Po raz pierwszy rzeczownik pokutnica pojawia się w SL. Notują go również SWil, SW i SJPD. W USJP zaznaczono książkowe i religijne nacechowanie analizowanego leksemu. We współczesnych tekstach religijnych leksem ten nie występuje. W Zgromadzeniu jest natomiast używany na określenie dziewcząt, które przebywały w prowadzonych dawniej przez siostry zakładach poprawy. Sądzę, że znaczenie, jakie, wyraz pokutnica ma w środowisku sióstr, uprawnia do zakwalifikowania go nie do archaizmów leksykalnych, ale do archaizmów rzeczowych bądź historyzmów (Markowski 2012: 165).

Kandydatka do Zgromadzenia, która przebywa w domu zakonnym i poznaje życie zakonne, w analizowanych dokumentach nazywana jest próbantka albo probantka: „Ponieważ zaś celem pierwszej próby jest nie tylko poznanie dokładne probantki, ale i jej obeznanie się z naszym życiem, ztąd będzie miała udział we wszystkich naszych wspólnych duchownych ćwiczeniach" (U 715). Leksem ten jest motywowany nazwą męską probant. Rzeczownik próbantka w SL oznacza tę, 'która, w klasztorze na próbie, nowicyuszkę'. To samo znaczenie notują również SWil, SW, SJPD i USJP. Współcześnie leksem ten nie jest używany (choć formę męską USJP rejestruje z kwalifikatorem religijny, a przy formie żeńskiej jest stosowny odsyłacz). Zastąpił go wyraz kandydatka, lecz jego znaczenie jest węższe. Współcześnie kandydatka to synonim aspirantki ${ }^{6}$, ale coraz częściej leksemem

${ }^{5}$ Za skrótem U (oznaczającym Ustawy Zgromadzenia Sióstr Opatrzności) odnotowano cyfrą arabską numer strony.

${ }^{6}$ Siostry mianem kandydatka określają często zarówno aspirantki, jak i postulantki, mimo że leksemy te odnoszą się do osób na dwóch różnych etapach formacji. Być może powodem tego jest to, że zarówno aspirat, jak i postulat to etapy początkowe, a dziewczyny i kobiety, które je odbywają, nie noszą jeszcze habitu i nie są nazywane siostrami. 
tym określane są osoby, które zgłaszają chęć wstąpienia do Zgromadzenia, choć jeszcze w nim nie przebywają.

Siostrę, która zarządzała spiżarnią, nadzorowała gospodarstwo i miała pieczę nad kluczami, nazywano dawniej szafarką: „Pod sobą będzie miała [ekonomka domu - M.W.] szafarkę i westyarkę, którym część swych obowiązków [...] powierzy [...]" (ZU II, 52). Nazwę szafarka utworzono sufiksem feminatywnym -ka od rzeczownika szafarz. Notacje leksemu szafarka w SL (w tym słowniku leksem ten pojawia się po raz pierwszy), SWil i SW zawierają odniesienie do życia zakonnego. W SJPD i w USJP brak takiego wskazania. Obecnie wyraz szafarka nie jest używany. Został zastąpiony leksemem magazynierka ${ }^{7}$.

W tym fragmencie występuje jeszcze jeden wyraz, który można traktować jako zapomniany. To leksem westyarka. Westyarka miała pieczę nad miejscem przechowywania odzieży sióstr. Jest to - jak podaje SL - żeński derywat od rzeczownika westyarnia 'w klasztorach szatnia, szatownia' (w SWil, SW - postać westjarnia). Natomiast leksemu westyarka słowniki nie notują.

Kolejnym wyrazem, który został zastąpiony przez nowszy, jest derywowany od czasownika uświatobliwić 'uczynić świątobliwym' (SW) rzeczownik uświątobliwienie: „Te, które zechcą dla chwały Bożej poświęcić swoje życie w tem domu, powinny przedewszystkiem starać się usilnie o własne uświątobliwienie w przekonaniu, że ono prędzej doprowadza nas do celów powołania naszego, aniżeli wszelkie powierzchowne, wrodzone lub nabyte przymioty" (ZU I, 2). Notuje go jedynie SW. Współcześnie wyraz ten został zastąpiony leksemem uświęcenie.

W analizowanych dokumentach oprócz wyrazów, które współcześnie nie są używane, funkcjonują również zapomniane związki wyrazowe. W ZU, jak i w U występuje na przykład połączenie cnota gruntowna: ,[... ] główna całego Zgromadzenia Przełożona, przekonawszy się [...] o jej [profeski czasowej M.W.] statku w powołaniu, o dokładnem zachowaniu ślubów, cnocie gruntownej i zdolności do posług naszego Zgromadzenia, udzieli jej zezwolenia [na złożenie ślubów wieczystych - M.W.]" (U 74-75). W SJPD zestawienie to występuje w przykładzie ilustrującym znaczenie wyrazu gruntowny, którego eksplikacja brzmi podobnie jak w SWil - 'fundamentalny, na dobrym gruncie założony, mocny, stały'. USJP definiuje znaczenie rzeczownika cnota jako 'zespół dodatnich cech moralnych; prawość, szlachetność, zacność', co notują także wszystkie wcześniejsze słowniki. Występujące w analizowanych dokumentach zestawienie cnota gruntowna, jest regularne semantycznie i oznacza (co możemy odczytać z kontekstu) stałą i wypróbowaną szlachetność i prawość w postępowaniu. Obecnie nie używa się również występującego w cytowanym fragmencie określenia statek w powoła-

${ }^{7}$ Wyniki analizy formalno-semantycznej wyrazów i grup wyrazowych nazywających członkinie społeczności, jaką jest Zgromadzenie Sióstr Opatrzności Bożej, zob. Wojtaszek M. s., Kto jest kim w domu zakonnym? O sposobach nominacji na przykładzie Zgromadzenia Sióstr Opatrzności Bożej (w druku). 
niu oznaczającego stałość w powołaniu. Rzeczownik statek w znaczeniu 'stałość, stateczność' jest poświadczony we wszystkich słownikach prócz USJP'.

Kolejnym zapomnianym związkiem wyrazowym jest frazeologizm ćwiczyć kogoś w duchu pokory: „Mając dawać pokuty lub upomnienia za uchybienia rzeczywiste, lub też aby swe córki w duchu pokory éwiczyć, powinna mieć [przełożona-M.W.] wzgląd na usposobienie osób [...]" (ZU II, 36). SJPD w przykładach ilustrujących znaczenie hasła ćwiczyć notuje zwrot ćwiczyć kogoś w pobożności. W USJP drugie znaczenie czasownika ćwiczyć brzmi 'doskonalić w czymś, wprawiać w czymś, kształcić; trenować'. W analizowanych dokumentach agensem czynu opisywanego jako ćwiczenie kogoś $w$ duchu pokory jest przełożona9. $\mathrm{Na}$ mocy władzy, jaką z racji pełnionego urzędu ma nad siostrami, stosuje odpowiednie środki - pokuty lub upomnienia, których celem jest ukształtowanie w siostrach postawy naznaczonej pokorą ${ }^{10}$.

Zadawane siostrom pokuty i upomnienia były również formą kary za popełnione przewinienie. W cytowanym fragmencie występuje też frazeologizm dawać pokuty. Agensem czynu opisywanego jako dawanie pokut również jest przełożona. Zakres praw do dawania pokut był uzależniony od rodzaju wykonywanej władzy. Tylko przełożona generalna, która piastowała najwyższą władzę w Zgromadzeniu, miała prawo dawać siostrom pokuty w każdym miejscu, w każdym czasie i za każde przewinienie. Oprócz tego przełożona generalna mogła zmienić rodzaj pokuty lub zwolnić siostry od pokut, do których wypełnienia zostały zobowiązane przez przełożone niższe ${ }^{11}$.

Obecnie w Zgromadzeniu Sióstr Opatrzności Bożej istnieje praktyka dawania pokut, ale nie jest ona obwarowana przepisami konstytucji. Siostrę może dziś upomnieć nie tylko przełożona, ale każda siostra. Zwrócenie uwagi na niewłaściwe zachowanie traktowane jest jako braterskie upomnienie, mające swe źródło w Ewangelii: „Gdy brat twój zgrzeszy przeciw tobie, idź i upomnij go w cztery oczy" (Mt 18, 15) ${ }^{12}$. Pokuta zadawana przez przełożoną jest dziś jednocześnie formą kary i zadośćuczynienia, ale też okazją do ćwiczenia się w pokorze. Naj-

${ }^{8}$ Brak dalszych tomów SPXVI nie pozwala na sprawdzenie w nim omawianego leksemu (nie korzystałam z kartoteki słownika).

9 Przełożoną jest każda siostra, która ze względu na pełnioną funkcję ma władzę nad innymi siostrami. Może nią być przełożona generalna, przełożona lokalna, mistrzyni itp.

${ }^{10}$ Wyraz pokora jest dziś rzadko używany i ma w języku ogólnym nieco negatywne zabarwienie, przykładowo USJP definiuje go (z kwalifikatorem książk.) jako 'stan psychiczny polegający na odczuwaniu własnej niedoskonałości, uniżona postawa wobec kogoś, czegoś, brak buntu wobec przeciwności; potulność, uległość, uniżoność'. W środowisku sióstr zakonnych leksem pokora ma pozytywne nacechowanie.

${ }^{11} \mathrm{~W}$ zakonach i zgromadzeniach zakonnych rozróżnia się przełożonych wyższych i przełożonych niższych. Przełożeni wyżsi zarządzają całym instytutem lub jego częścią. Zalicza się do nich m.in. przełożonych generalnych i zastępujących ich wikariuszy, przełożonych prowincjalnych i ich wikariuszy. Przełożonymi niższymi w zakonach o strukturze hierarchicznej są przełożeni domów zakonnych (Wytrwał 2012: 641).

${ }^{12}$ Cytowany fragment pochodzi z: BJ 2006: 1385. 
częściej siostry dostają pokutę za zniszczenie lub uszkodzenie rzeczy należącej do wspólnego użytku. Zgłaszają przełożonej rodzaj wyrządzonej szkody i proszą o zadanie pokuty. W związku z tą praktyką w mowie sióstr funkcjonuje frazeologizm iść po pokute (Idę do przełożonej po pokute).

Związkiem wyrazowym, który dziś już nie występuje, jest frazeologizm mieć gruntowne nabożeństwo: „Przełożona miejscowa [...] ma przedewszystkiém mieć gruntowne nabożeństwo, aby mogła w modlitwie czerpać potrzebne światło do dobrego rządu i moc umysłu" (ZU II, 34). Zwrot ten dotyczy kogoś, kto jest pobożny i stały w modlitwie. To cecha, której - zgodnie z zapisami w analizowanych dokumentach - wymaga się przede wszystkim od przełożonej. Rzeczownik nabożeństwo oznacza tu 'pobożność, pobożne postępowanie zgodne z przepisami religijnymi' (SStp). Znaczenie to - jako pierwsze - odnotowują także SPXVI, ESJP XVII-XVIII, SL i SWil. W SJPD znaczenie to podane jest jako trzecie i ma kwalifikator przestarzały. Nie odnotowuje go natomiast USJP.

Droga od wstąpienia do Zgromadzenia do złożenia profesji - czasowej i wieczystej - podzielona jest na kilka etapów. Pierwszy etap pobytu w Zgromadzeniu był dawniej nazywany pierwsza próbą: „Ponieważ prawo przyjęcia do Zgromadzenia jedynie do głównej całego Zgromadzenia Przełożonej należy, z tąd nikogo ani nawet do pierwszej próby, a tem mniej do Nowicyatu bez wyraźnego jej rozkazu nie przyjmie [mistrzyni nowicjatu - M.W.]" (U 68). Pierwsza próba poprzedzała nowicjat. Kandydatka przyglądała się z bliska życiu sióstr i ich posłudze, włączała się w codzienne prace, rozeznawała swoje powołanie i decydowała, czy chce zostać w Zgromadzeniu, czy je opuścić. Także przełożone przyglądały się kandydatce i decydowały, czy ich zdaniem nadaje się ona do życia zakonnego. Zestawienia pierwsza próba nie odnotowują słowniki. Współcześnie ${ }^{13}$ określenie to również nie występuje. Zastąpiły je leksemy aspirat i postulat.

W refektarzu, czyli zakonnej jadalni, stało zwykle kilka stołów. Stół, przy którym siedziała przełożona generalna wraz z zarządem Zgromadzenia lub przełożona domu z zarządem domowym, nazywany był pierwszym stołem: „U pierwszego stołu będzie wspólne błogosławieństwo i dziękczynienie, jako też czytanie książki od Przełożonej naznaczonej” (ZU II, 39). Liczebnik porządkowy pierwszy, który poprzedza rzeczownik stót, wskazywał na hierarchię, zgodnie z którą siostry zajmowały miejsce przy stole. SJPD w artykule hasłowym do stót podaje, że używane dawniej określenia pierwszy, drugi, trzeci stót oznaczały różne rodzaje posiłków dla państwa, domowników i służby. Pozostałe słowniki nie notują tego zestawienia. W Zgromadzeniu mówi się współcześnie o głównym stole, mając na myśli stół w refektarzu w domu generalnym Zgromadzenia, przy którym siadają przełożona generalna, przełożona lokalna i siostry z zarządu, a w czasie uroczystości biskup, spowiednik, rekolekcjonista itp.

${ }_{13}$ Pisząc, że „wyraz lub połączenie wyrazowe współcześnie nie występuje”, mam na myśli to, że nie jest obecne ani w najnowszych dokumentach Zgromadzenia, ani w mowie sióstr, ani we współczesnych tekstach religijnych. 
Siostrom powierzane były do spełnienia różne obowiązki. Zadania polegające na formowaniu sióstr, prowadzeniu modlitw itp. nazywane są w dokumentach postuga duchowna, a praca fizyczna postuga cielesna: „Opisanie osoby mającej być do ślubów czy rocznych, czy dożywotnych przypuszczoną [...] powinno zawierać [...] odpowiedzi, a to na każde z osobna z następujących pytań 15 stu. [...] Jakie sprawowała urzędy, lub posługi bądź duchowne bądź cielesne?" (U 104-105). Zestawienia te są notowane w słownikach (SW i SJPD) w przykładach ilustrujących znaczenie leksemu postuga, z tym że w SJPD postuga duchowna jest eksplikowana jako 'udzielanie sakramentów kościelnych', co nie odpowiada znaczeniu, jakie ma $\mathrm{w}$ analizowanych dokumentach. Współcześnie żadne $\mathrm{z}$ tych zestawień nie występuje. Używane jest określenie postuga duchowa $\mathrm{w}$ znaczeniu, jakie SJPD przypisuje postudze duchownej.

Analizowane dokumenty zawierają nazwę jeszcze jednego rodzaju postugi posługa niska: „Aby podrzędne swe przykładem do pracy pobudzić, sama [przełożona - M.W.] niekiedy odprawywać będzie niskie posługi, ciesząc się iż w tem P. Jezusa naśladować może, i córki swe zachęcać do tego" (U 80). Mianem postuga niska określane są w dokumentach proste prace fizyczne, np. zmywanie naczyń, mycie podłogi, ścieranie kurzu. Zestawienie to notuje jedynie SPXVI. Współcześnie nie jest ono używane.

Troska o duchowy wzrost jest stałym zadaniem osoby konsekrowanej. Określeniu duchowy wzrost $\mathrm{w}$ analizowanych dokumentach odpowiada frazeologizm postępek duchowny: „Niech każda będzie przygotowaną, że najlichsze i najgorsze rzeczy w domu znajdujące się będą jej do użytku dane, ażeby tym sposobem dopomódz jej do tem większego nabycia zaparcia się samej siebie i do większego postępku duchownego" (ZU I, 6). Wyrażenie postępek duchowny nie jest notowane w słownikach (w SL postępek jest synonimem postępu, SW notuje określenie postęp duchowy) i współcześnie nie jest używane.

Funkcjonującemu dzisiaj określeniu wzrastać duchowo w analizowanych dokumentach odpowiada frazeologizm róść w nabożeństwie: „Życzyć sobie powinny, ażeby inne nad nie były wywyższone [...]. Tym sposobem patrząc jedna na drugą, będą wszystkie róść w nabożeństwie i chwalić Pana i Boga naszego [...]" (U 13). Zwrotu róść w nabożeństwie słowniki nie notują. W SJPD - w cytacie ilustrującym znaczenie czasownika rosnać - pojawia się jedynie wyrażenie rosnać w madrości i pobożności. Kontekst, w jakim frazeologizm występuje w dokumentach, wskazuje, że leksem nabożeństwo - podobnie jak w analizowanym wcześniej frazeologizmie mieć gruntowne nabożeństwo - oznacza 'pobożność, cześć ku Bogu; uczucie wypływające z wiary w Boga i z miłości Boga, skąd cześć Boga wyrażająca się modlitwą'. Zwrot róść w nabożeństwie nie jest obecnie używany.

Ślubując posłuszeństwo, każda siostra zobowiązuje się do podporządkowania się przełożonym. Relacja ta wypływa z wiary, że przełożeni są narzędziami w ręku Boga, przy których pomocy On sam kieruje życiem każdej siostry. Zawierzenie przełożonym, zdanie się na nich jest wyrażane w badanym materiale m.in. za 
pomocą związku frazeologicznego spuścić się na wolę przełożonych: „[...] niech ją [aspirantkę - M.W.] dokładnie badają. [...] Czy ma szczerą chęć poświęcenia zupełnie służbie Boskiej według naszego powołania [...] spuszczając się zupełnie na wolę Przełożonych, z zupełną czy co do miejsca, czy co do urzędów i posług obojętnością?" (ZU II, 29-30). Frazeologizmu w tym kształcie słowniki nie rejestrują. SStp, ESJP XVII-XVIII, SL i SW notują czasownik spuścić się (spuszczać się) w znaczeniu 'polegać na kim', a SWil, SJPD i USJP poświadczają zwrot spuścić się na kogo, na co w znaczeniu 'zaufać, że ktoś dobrze wykona zleconą mu pracę, że coś okaże się dobre, wartościowe, sprawne, zdać się na kogoś, na coś, oprzeć na kimś, na czymś swoje nadzieje', przy czym w USJP frazeologizm ten jest kwalifikowany jako przestarzaty.

Andrzej Markowski podaje dwie przyczyny wychodzenia z użycia wyrazów i frazeologizmów. Jedną jest zanik desygnatów oznaczanych przez wyraz, drugą - ,zastępowanie starszych nazw i określeń nowszymi, odnoszonymi do tych samych rzeczy, zachowań, cech czy czynności" (Markowski 2012: 165). Do wymienionych $\mathrm{w}$ artykule wyrazów i związków wyrazowych, które wyszły z użycia w związku z zanikiem desygnatu, należą rzeczowniki admonitorka, pokutnica, westyarka. Większość leksemów i połączeń wyrazowych została zastąpiona przez nowsze określenia (domniemane zezwolenie przetożonej - domyślne zezwolenie przełożonej, infirmerka - pielęgniarka, pierwszy stót - główny stót, próbantka kandydatka, szafarka - magazynierka itd.).

Prawie wszystkie wymienione przeze mnie zapomniane wyrazy i związki wyrazowe wyekscerpowane z dokumentów Zgromadzenia Sióstr Opatrzności Bożej to archaizmy leksykalne (Markowski 2012: 166), np. admonitorka, cnota gruntowna, ćwiczyć kogoś w duchu pokory, róść w nabożeństwie, szafarka, westyarka. Archaizmem rzeczowym jest leksem pokutnica. Najczęściej powtarzającymi się $\mathrm{w}$ analizowanym materiale wyrazami są rzeczowniki admonitorka (ZU - 1914, $\mathrm{U}-18)$ i pokutnica (ZU - 19, U - 18), następnie próbantka $(Z \mathrm{U}-8, \mathrm{U}-7)$ i kolejno frazeologizmy dawać pokuty $(\mathrm{ZU}-4, \mathrm{U}-4)$, cnota gruntowna $(\mathrm{ZU}-3$, $\mathrm{U}-3)$, rzeczownik szafarka $(\mathrm{ZU}-3, \mathrm{U}-3)$ i wyrażenie postępek duchowny (ZU - 4, U - 1). Pozostałe leksemy występują w badanym materiale mniej niż 6 razy. Leksemy cnota i pokora nabrały nieco negatywnego zabarwienia, zwłaszcza w rzeczywistości laickiej.

W książce Pamięć i tożsamość Jan Paweł II zwrócił uwagę na to, że

Narody utrwalają swoje dzieje w opracowaniach, przekazują w różnorakich formach dokumentów, dzięki którym tworzą własną kulturę. Podstawowym narzędziem tego sukcesywnego tworzenia jest język. Za jego pomocą człowiek wypowiada prawdę o świecie i o sobie samym [...], a to służy wymianie myśli, głębszemu poznaniu prawdy, a przez to samo również pogłębianiu i gruntowaniu własnej tożsamości (Jan Paweł II 2005: 33).

${ }^{14}$ Za skrótami ZU oraz U podano liczbę wystąpień leksemu w danym tekście. 
W podobny sposób wypowiadają się językoznawcy. Zdaniem Ryszarda Tokarskiego „Każde wyrażenie językowe tworzy sobie tylko właściwy semantyczny «mikroświat», w którym odbijają się ludzkie pragnienia, sposoby porządkowania i oceny rzeczywistości” (2013: 35). Z kolei Markowski wyraża opinię, że ,język jest [...] zwierciadłem historii narodu, który tego języka używa, można z niego odczytać system wartości uznawany przez naszych przodków, poznać ich tradycje, zwyczaje, a także sposoby myślenia; wszystko to bowiem zakrzepło w strukturze znaczeniowej i słowotwórczej wielu wyrazów" (2009: 11).

Analiza wyrazów zapomnianych występujących w dokumentach żeńskiego zgromadzenia zakonnego, a więc wspólnoty praktyków ${ }^{15}$, pozwala zajrzeć w świat minionych pokoleń sióstr, poznać choć w części ich pragnienia i sposób wartościowania oraz dostrzec zależność między przeszłością a teraźniejszością. Traktuję ją jako specyficzną formę odpowiedzi na zachętę papieża Franciszka, który wzywał osoby konsekrowane, aby wspominały swoją wspaniałą przeszłość, opowiadały o niej i nią wzbogacone budowały nową, wielką historię (Franciszek b.r.). Leksyka analizowanych dokumentów jest również skarbnicą wiedzy o przeszłości Zgromadzenia Sióstr Opatrzności Bożej, spoiwem i istotnym składnikiem jego tożsamości. Warto, by była traktowana jako wartość - uznawana, kultywowana i chroniona (Markowski 2009: 12).

\section{ŹróDeA}

U - Ustawy Zgromadzenia Sióstr Opatrzności, Lwów 1882.

ZU - Zbiór Ustaw Zgromadzenia Panien Opatrzności, cz. I-II, Lwów 1857.

\section{Bibliografia}

Ahearn Laura A., 2013, Antropologia lingwistyczna, Kraków.

BJ - Biblia Jerozolimska, Poznań 2006.

Franciszek, 2014, List apostolski do wszystkich osób konsekrowanych z okazji Roku Życia Konsekrowanego, https://w2.vatican.va/content/francesco/pl/apost_letters/documents/ papafrancesco_lettera-ap_20141121_lettera-consacrati.html [dostęp: 23.09.2015].

Grzegorczykowa $\mathrm{R}$., 2012, O istocie, zakresie i cechach swoistych języka religijnego, w: R. Grzegorczykowa, Świat widziany poprzez stowa. Szkice z semantyki leksykalnej, Warszawa, s. 256-263.

Jan Paweł II, 2005, Pamięć i tożsamość, Kraków.

${ }^{15}$ Laura M. Ahearn wśród wspólnot użytkowników języka wyróżnia wspólnotę praktyków. Tym mianem nazywa „zbiorowość ludzi, którzy gromadzą się wokół interaktywnego zaangażowania w jakieś przedsięwzięcie. [...] Jako twór społeczny wspólnota praktyków różni się od tradycyjnej wspólnoty przede wszystkim dlatego, że jest ona definiowana jednocześnie przez członkostwo" (2013: 119). Wśród przykładów wspólnot praktyków wymienia członków zgromadzenia religijnego. 
SW - Karłowicz J., Kryński A., Niedźwiedzki W., Słownik języka polskiego, t. 1-8, Warszawa 1900-1927, http://ebuw.uw.edu.pl/dlibra/publication?id=254 [dostęp: 8.07.2016].

Korczak J., 1992, Dziecko salonu, w: Dzieła, t. 1, Warszawa.

Kumaniecki K., 1983, Słownik łacińsko-polski według słownika Hermana Mengego i Henryka Kopii, Warszawa.

SL - Linde S.B., Słownik języka polskiego, t. 1-6, Warszawa 1807-1814, http://kpbc.umk. pl/publication/8173 [dostęp: 8.07.2016].

Markowski A., 2009, Kultura języka polskiego. Teoria. Zagadnienia leksykalne, Warszawa.

Markowski A., 2012, Wykłady z leksykologii, Warszawa.

SJPD - Słownik języka polskiego, t. 1-11, red. W. Doroszewski, Warszawa 1958-1969, http://doroszewski.pwn.pl/ [dostęp: 8.07.2016].

ESJP XVII-XVIII - Elektroniczny słownik języka polskiego XVII i XVIII wieku, Kraków 1996-, http://xvii-wiek.ijp-pan.krakow.pl/pan_klient/index.php [dostęp: 8.07.2016].

SPXVI - Słownik polszczyzny XVI wieku, t. 1-36, red. M.R. Mayenowa (później F. Pepłowski, K. Mrowcewicz), Wrocław-Warszawa-Kraków 1966-2012, http://kpbc. umk.pl/publication/17781 [dostęp: 8.07.2016].

SStp - Słownik staropolski, t. 1-11, red. S. Urbańczyk, Kraków 1953-2002, http://www. rcin.org.pl/publication/39990 [dostęp: 8.07.2016].

USJP - Uniwersalny słownik języka polskiego PWN, red. S. Dubisz, E. Sobol, wersja 2.0, Warszawa 2006.

Wojtaszek M. s., 2016, Nasza historia, Zielona Góra.

Wojtaszek M. s., w druku, Kto jest kim w domu zakonnym? O sposobach nominacji na przykładzie Zgromadzenia Sióstr Opatrzności Bożej.

Wytrwał T., 2012, Przełożony, w: Encyklopedia katolicka, red. E. Gigilewicz, t. 16, Lublin, s. 64 .

SWil - Zdanowicz A. (i in.), Słownik języka polskiego, cz. 1-12, Wilno 1861, http://eswil. ijp-pan.krakow.pl/ [dostęp: 8.07.2016]. 
